\title{
Pendampingan dan Sosialisasi Peran Supervisor Model 4S Dalam Membimbing Perilaku Caring Perawat dan Pelaksanaan Spiritual Care Islam
}

\author{
Dewi Mustikaningsih \\ Sekolah Tinggi Ilmu Kesehatan Aisyiyah Bandung \\ Email: aning_klw@ymail.com
}

\begin{abstract}
Abstrak
Supervisor 4S sebagai model supervisi kepala ruang ke ketua tim dan perawat pelaksana dapat diimplementasikan perannya dalam membimbing perilaku caring perawat dan pelaksanaan spiritual care Islam. Pengabdian masyarakat ini bertujuan untuk meningkatkan kemampuan pengetahuan dan keterampilan kepala ruang dan ketua tim dalam melakukan bimbingan perilaku caring perawat dan pelaksanaan spiritual care Islam. Khalayak sasaran pengabdian masyarakat ini adalah kepala ruang dan ketua tim. Pendampingan dan sosialisasi ini dilakukan dengan cara metode ceramah, tanya jawab, diskusi dan demonstrasi yang diikuti oleh 25 orang. Hasil pengabdian masyarakat ini untuk tingkat pengetahuan kepala ruang dan ketua tim sebelum dan sesudah sosialisasi dalam kategori baik (100\%) dan untuk aspek sikap pelaksanaan sebelum dan sesudah pendampingan dalam kategori cukup baik (87\%). Tingkat pengetahuan dan sikap kepala ruang dan ketua tim setelah diberikan pendampingan dan sosialisasi peran supervisor model 4S sebagian besar baik dalam melakukan supervisi.
\end{abstract}

Kata Kunci: Supervisor 4s, kepala ruang, ketua Tim

\section{Abstract}

The 4S supervisor as a supervisory model for the head of the room to the team leader and the nurse executing his role in guiding the caring behavior of nurses and the implementation of Islamic spiritual care. This community service aims to improve the knowledge and skills of the head of the room and the team leader in guiding nurse caring behavior and implementing Islamic spiritual care. The target audience for this community service is the head of the room and the team leader. This assistance and outreach was carried out by means of lectures, question and answer methods, discussions and demonstrations attended by 25 people. The results of this community service for the level of knowledge of the head of the room and the team leader before and after the socialization were in the good category (100\%) and for the aspect of the attitude of the implementation before and after the mentoring was in the quite good category (87\%). The level of knowledge and attitudes of the head of the room and the team leader after being given assistance and socialization of the role of the $4 S$ supervisor model are mostly good in conducting supervision.

Keywords: Supervisor 4s, head of room, team leader

\section{PENDAHULUAN}

Model supervisi 4S ini diperkenalkan oleh Page dan Wosket dari hasil penelitiannya pada tahun 1995 dan dikembangkan lagi di tahun 2010 dengan model supervisor yang terdiri dari empat (4) strategi, yaitu structure, skills, support dan sustainability. Kegiatan structure dilakukan oleh perawat yang sudah teregistrasi Ners dalam melakukan pengkajian dan asuhan pasien dimana perawat yang dibina sekitar 6-8 orang. Tujuan kegiatan ini adalah untuk mengembangkan pengalaman perawat dalam hal konsultasi, fasilitasi dan assisting. Kegiatan skills dilakukan supervisor untuk meningkatkan keterampilan praktis dalam masalah keperawatan spiritual Islam (contoh: membimbing tayamum, doa, shalat dengan duduk/berbaring, istinja'dsb). Kegiatan support dilakukan dengan tujuan untuk memberikan praktik kebaruan, sharing, kebutuhan-kebutuhan training tertentu yang bernilai kebaruan (contoh: pelatihan SEFT pada pasien paliatif). Kegiatan sustainability bertujuan untuk tetap mempertahankan pengalaman, ketrampilan, nilai-nilai yang telah dianut perawat. Kegiatan ini dilakukan secara kontinu dengan cara mentransfer pengalaman supervisor kepada perawat pelaksana (contoh: supervisor membuat modul tentang berbagai keterampilan teknik dalam 
memberikan tindakan keperawatan dengan masalah spiritual Islam yang dibagikan kepada semua perawat pelaksana).

Perilaku caring dalam keperawatan Islam, bukan hanya asuhan kemanusiaan dengan lemah lembut berdasarkan standar dan etika profesi, tetapi caring yang didasari keimanan pada Allah Subhanahu Wa Ta'ala dengan menjalankan perintahNya melalui ayat-ayat Alqur'an dengan tujuan akhir mendapatkan ridho Allah Subhanahu Wa Ta'ala (Fadhillah, 2009). Caring dalam Islam berarti kemauan untuk bertanggung jawab, memiliki jiwa sensitif, motivasi, dan komitmen untuk bertindak dalam urutan yang benar untuk mencapai kesempurnaan.

Fokus caring dalam Islam adalah membantu pasien mengenal kepercayaannya terhadap Allah Subhanahu Wa Ta'ala (Lovering, 2008:119 dalam Islamil et al.,2015). Islam mengajarkan praktek hubungan sosial dan kepedulian terhadap sesama yaitu dengan akhlaq. Dilakukan dengan mengamalkan dan mempraktekan yang diikuti unsur syari'ah dan aqidah. Praktek pelayanan di Rumah Sakit sebagian kecil merupakan pengamalan dan pengajaran akhlaq, maka seorang muslim harus melakukan pelayanan kesehatan dengan diniatkan karena ibadah. Akhlaq Islami yaitu perbuatan yang dilakukan dengan mudah, disengaja, mendarah daging, dan sebenarnya didasarkan atas ajaran Islam (Sukowati, 2013).

Penelitian Mustikaningsih tentang faktor - faktor yang berhubungan dengan perilaku caring perawat dalam memberikan spiritual care Islam menunjukkan bahwa faktor organisasi dan manajemen dalam kategori baik dan sebagai faktor yang berhubungan dengan perilaku caring perawat dalam memebrikan spiritual care Islam (Mustikaningsih.D, 2015). Organisasi dan manajemen yang dimaksud dalam penelitian tersebut adalah fungsi pengarahan yaitu adanya supervisi kepada perawat.

Berdasarkan penelitian tentang peran supervisor model 4S dengan perilaku caring perawat dan pelaksanaan spiritual care Islam menghasilkan identifikasi peran supervisor model 4S dalam kategori baik yaitu 55 (88.7\%), identifikasi perilaku caring perawat dalam kategori baik yaitu 55 (88.7\%), identifikasi pelaksanaan spiritual care Islam dalam kategori cukup yaitu $33(53,2 \%)$ (Mustikaningsih D, 2018).

Supervisor dalam memberikan bimbingan bukan hanya melalui perilaku caring Islam saja tetapi pelaksanaannya dapat diwujudkan secara holistik melalui pelaksanaan asuhan keperawatan yang mencerminakan nilai-nilai Islam (spiritual care Islam).

Rumah Sakit Muhammadiyah Bandung (RSMB) memiliki visi menjadi rumah sakit Islam unggulan di Jawa Barat tahun 2018. Misi keperawatan RSMB yaitu menyelenggarakan pelayanan keperawatan profesional dan Islami. Menurut kepala bidang keperawatan bahwa kepala ruang dan ketua tim pernah diberikan pelatihan supervisi klinik keperawatan model 4S pada tahun 2013, pelatihan model pelayanan keperawatan tim primer pada tahun 2014 dan perilaku caring perawat dalam memberikan spirital care Islam pada tahun 2015.

Hasil wawancara dengan enam supervisor menyatakan selama ini dalam memberikan bimbingan dan dorongan kepada perawat pelaksana hanya berfokus pada masalah masalah keperawatan secara umum dengan tekinik superviseiyang masih tradisional yaitu mencari kesalahan yang dilakukan oleh perawat.

Berdasarkan wawancara dengan beberapa pasien mengatakan pelayanan di RSMB dikatakan cukup, beberapa pasien memberikan kritik atau keluhan terhadap pelayanan perawat di ruangan seperti pelayanannya masih kurang ramah, empati, kurang memperhatikan kebutuhan dasar pasien, kurang berkomunikasi dan kurang memenuhi kebutuhan dasar spiritualnya.

Berdasarkan wawancara dengan bidang keperawatan RSMB bahwa tahun 2018 belum melakukan evaluasi kinerja supervisor dan belum dilakukan lagi pendampingan dan sosialisasi peran supervisor di ruang rawat inap.

Berdasarkan latar belakang tersebut, peneliti tertarik untuk melakukan pengabdian masyarakat yaitu pendampingan dan sosialisasi peran supervisor model $4 \mathrm{~S}$ dalam membimbing perilaku caring perawat dan pelaksanaan spiritual care Islam. 


\section{BAHAN DAN METODE}

Metode yang dilakukan dalam pengabdian masyarakat ini adalah diskusi kelompok dengan metode focus group discussion (FGD) yang terdiri dari ceramah, diskusi, simulasi dan demonstrasi yang meliputi 1) pre dan post test, metode ini dilaksanakan untuk mengetahui tingkat pengetahuan sasaran sebelum dan sesudah pemberian informasi. Ceramah dan diskusi yaitu metode ini dipilih untuk menyampaikan konsep-konsep yang penting untuk dimengerti dan dikuasai oleh kepala ruang dan ketua tim. 2) metode ceramah, tanya jawab dikombinasikan dengan tanya jawab dan sharing pengalaman sehingga materi yang diberikan saat sosialisasi yang pertama bisa dilaksanakan di ruangan. Kepala ruang dan ketua tim juga diberikan kesempatan untuk bertanya atau sharing pengalaman terkait pelaksanaan supervisi yang sudah diterapkan di ruangan. 3) simulasi dan demonstrasi yaitu metode ini dipilih untuk menunjukkan suatu proses kerja yaitu tahap-tahap terutama untuk pelaksanaan simulasi teknik supervise model $4 S$ dalam membimbing perilaku caring perawat dan pelaksanaan spiritual care Islam di ruang rawat inap Rumah Sakit Muhammadiyah Bandung. 4) observasi, metode ini digunakan untuk melihat pelaksanaan supervisi yang dilakukan oleh sasaran setelah diberikan informasi dalam kegiatan sosialisasi Jenis pengabdian masyarakat berupa sosialisasi dengan pelatihan selama 2 hari dan pendampingan pelaksanaan supervise model $4 \mathrm{~S}$ selama 4 minggu, populasi seluruk kepala ruang dan ketua tim di ruang rawat inap berjumlah 25 orang, pengambilan sampel dengan teknik total sampling yang terdiri dari 10 orang kepala ruang dan 15 orang ketua tim. Teknik pengumpulan data menggunakan kuesioner tingkat pengetahuan peran supervisor model $4 \mathrm{~s}$, dan lembar observasi penilaian sikap pada pelaksanaan supervisi model 4S yang dilakukan oleh kepala ruang dan ketua tim. Kuesioner dan lembar observasi dinilai sebelum dan sesudah diberikan pendampinagn dan sosialisasi.

\section{HASIL}

Karakteristik responden meliputi usia, jenis kelamin, tingkat pendidikan, lama kerja dan status perkawinan. Karakteristik responden yang terdiri dari umur dengan hasil sebagian besar memiliki usia lebih dari 31 tahun yaitu sebanyak 21 orang (92\%), jenis kelamin sebagian besar responden berjenis kelamin perempuan yaitu sebanyak 20 orang (83\%) dan sebagian kecil responden berjenis kelamin laki-laki yaitu sebanyak 3 orang (13\%), tingkat pendidikan sebagian besar responden berpendidikan D3 Keperawatan yaitu sebanyak 21 orang (91\%) dan sebagian kecil responden memiliki pendidikan Ners yaitu sebanyak 2 orang (8\%), masa kerja sebagian besar masa kerja menjadi kepala ruang dan ketua tim yang bekerja di Rumah Sakit Muhammadiyah Bandung selama 1-10 tahun yaitu sebanyak 20 orang (87\%), status perkawinan sebagian besar status perkawinan kepala ruang dan ketua tim yang bekerja di Rumah Sakit Muhammadiyah Bandung adalah $100 \%$ sudah menikah.

Tingkat pengetahuan kepala ruang dan ketua tim tentang supervisi model $4 \mathrm{~S}$ sebelum dan sesudah diberikan pendampingan, hasil menunjukkan bahwa sebelum mendapatkan sosialisasi supervisi model $4 \mathrm{~S}$ sebagian besar responden memiliki tingkat pengetahuan pada kategori rendah yaitu $43 \%$, sedangkan setelah mendapatkan sosialisasi dalam bentuk pelatihan, tingkat pengetahuan kepala ruang dan ketua tim dalam kategori tinggi yaitu $100 \%$.

Sikap pelaksanaan supervisi model $4 S$ kepala ruang dan ketua tim sebelum dan sesudah diberikan pendampingan, menunjukkan bahwa sebelum mendapatkan pendampingan supervisi model $4 \mathrm{~S}$ sebagian besar responden memiliki sikap pada kategori kurang baik yaitu $43 \%$, sedangkan setelah mendapatkan pendampingan supervisi model $4 \mathrm{~S}$ dalam kategori cukup baik yaitu $87 \%$.

\section{PEMBAHASAN}


Karakteristik responden berhubungan dengan tingkat pengetahuan dan sikap dalam pelaksanaan pendampingan dan sosialisasi peran supervisor model $4 S$. Usia dapat mempengaruhi produktifitas kerja seseorang, usia juga mempengaruhi pandangan petugas terhadap atasan maupun pasien. Hasil kuesioner ini didukung oleh penelitian Elita (2011) menyatakan bahwa usia akan mempengaruhi karakter dalam mempelajari, memahami serta menerima suatu perubahan sehingga akan berpengaruh terhadap kualitas dan kuantitas kerja seseoang. Usia dapat mempengaruhi produktifitas kerja, karena kemampuan kerja seseorang dibatasi oleh faktor usia.

Jenis kelamin tidak berhubungan dengan tingkat pengetahuan dan sikap tetapi berhubungan dengan kinerja perawat, hal ini sesuai dengan penelitian Ahmadi (2009) bahwa kinerja perawat terhadap kualitas pelayanan di Rumah Sakit Riyadh Saudi Arabia yang menyatakan bahwa jenis kelamin berkorelasi positif terhadap kinerja. Supervisi merupakan salah satu fungsi yang penting dilakukan untuk meningkatkan kinerja perawat (Mulyaningsih, 2013).

Tingkat pendidikan juga berhubungan dengan pengetahuan dan sikap seseorang. Menurut Anggraini dalam Gatot dan Adisasmito (2005) bahwa semakin tinggi tingkat pendidikan akan semakin tinggi keinginan untuk memanfaatkan pengetahuan dan keterampilan.

Lama kerja juga berhubungan dengan kinerja seseorang. Berdasarkan hasil penelitian Warouw (2009) menyatakan bahwa lama bekerja dapat meningkatkan kinerja jika didukung dengan pendidikan dan pelatihan. Bimbingan dan pengalaman dalam bekerja bagi kepala ruang dan ketua tim sangat diperlukan dengan memberikan kesempatan untuk mengikuti pelatihan. Lama kerja seorang tenaga kesehatan untuk melakukan jenis pekerjaan tertentu dinyatakan dalam lamanya waktu selama melaksanakan tugas tersebut. Karakteristik lain adalah status perkawinan bahwa seseorang lebih cepat dewasa, bijaksana dan bisa memecahkan masalah dengan baik.

Tingkat pengetahuan kepala ruang dan ketua tim tentang supervisi model 4S sebelum dan sesudah diberikan pendampingan dalam kategori tinggi. Pengetahuan didapatkan melalui pengalaman pribadi yang terjadi berulang kali termasuk didalamnya adalah proses pengajaran (Notoatmodjo, 2007). Pengetahuan adalah informasi yang dapat merubah seseorang atau sesuatu, dimana pengetahuan itu menjadi dasar dalam bertindak atau pengetahuan itu menjadikan seseorang individu atau institusi memiliki kecakapan dalam melakukan tindakan yang benar seperti melaksanakan supervisi dengan benar (Pribadi, 2009).

Sikap pelaksanaan supervisi model $4 S$ kepala ruang dan ketua tim sebelum dan sesudah diberikan pendampingan menunjukkan hasil dalam kategori cukup baik. Kepala ruang merupakan seorang tenaga perawat profesional yang bertanggung jawab dan berwenang dalam mengelola kegiatan pelayanan keperawatan disuatu ruangan serta dalam menjalankan tugasnya mengacu pada standar yang telah ditetapkan dalam pelaksanaan supervisi keperawatan (Warouw, 2009). Berdasarkan hasil penelitian jurnal Graff, dkk (2012) menyatakan bahwa group kelompok perawat yang di supervisi memiliki tingkat pelayanan keperawatan terhadap pasien lebih baik serta lebih meningkatkan sikap dan keterampilan perawat dalam berinteraksi terhadap pasien. Kepala ruang dan ketua tim juga akan lebih optimal melakukan kegiatan supervise setelah mendapatkan secara optimal pendampingan dengan baik. Hal ini sesuai dengan penelitian Mustikaningsih,2013 bahwa pelaksanaan supervisi ketua tim cukup baik setelah diberikan pelatihan dan pendampingan teknik supervisi model $4 \mathrm{~S}$ pada kelompok control dan kelompok intervensi.

\section{KESIMPULAN DAN SARAN}

Kegiatan sosialisasi dan pendampingan peran supervisor model $4 \mathrm{~S}$ oleh kepala ruang dan ketua tim dalam membimbing perilaku caring perawat dan pelaksanaan spiritual care 
Islam merupakan bentuk kerjasama antara Rumah Sakit Muhammadiyah Bandung dengan STIKes 'Aisyiyah Bandung untuk mengaplikasikan peran fungsi manajemen yaitu fungsi pengarahan kepala ruang dan ketua tim di ruang rawat inap sehingga meningkatkan kualitas pelayanan keperawatan sesuai standar akreditasi Rumah Sakit secara Nasional. Kegiatan berlangsung lancar, pencapaian dapat dikatakan baik yaitu tingkat pengetahuan setelah diberikan sosialisasi meningkat yaitu kategori tinggi (100\%) dan sikap pelaksanaan supervisi kepala ruang dan ketua tim setelah diberikan pendampingan dalam kategori cukup baik yaitu $87 \%$.

Berdasarkan hasil evaluasi dari jumlah pencapaian target sasaran, masih banyak kepala ruang dan ketua tim yang belum optimal mendapat pendampingan teknik supervisi model 4S dikarenakan waktu dan biaya yang terbatas, sehingga disarankan kepada bidang keperawatan untuk melakukan rencana tindak lanjut pendampingan teknik supervisi model 4S kepada kepala ruang dan ketua tim di ruangan lain. Selain rencana tindak lanjut dari bidang keperawatan, hasil pengabdian masyarakat ini juga bisa dijadikan sebagai data awal dalam penelitian dengan topik penelitian pengaruh pelatihan model supervisi klinik keperawatan model $4 \mathrm{~S}$ kepala ruang dan ketua tim terhadap mutu pelayanan keperawatan di ruang rawat inap.

\section{UCAPAN TERIMA KASIH}

Terima kasih kepada Ketua STIKes 'Aisyiyah Bandung, direktur Rumah Sakit Muhammadiyah, kepala BP2MPK, manager SDI dan manager keperawatan yang telah memberikan bantuan, dukungan serta kontribusi pelaksanaan pengabdian masyarakat dan terselesainya penyusunan laporan ini.

\section{DAFTAR PUSTAKA}

Arwani. 2006. Manajemen supervisi. Jakarta: Grafindo

Kilminster et al. 2007. Effective supervision in clinical practice setting. Cambride conference medical education.

Mustikaningsih $D, 2013$. Pengaruh supervisi klinik model 4S terhadap kinerja perawat pelaksana dalam metode keperawatan tim.

Mustikaningsih D. 2016. Faktor - faktor yang berhubungan dengan perilaku caring perawat dalam pelaksanaan spiritual care Islam.

Mustikaningsih $D, 2018$. Hubungan supervisor model 4S dengan perilaku caring perawat dan pelaksanaan spritual care Islam.

Marquis ,B.L \& Huston,C.J (2012). Leadership role \& management functions in Nursing: Theory \& application (7th ed,p.642). Philadelphia:Lippincott Williams \& Wilkins

Nursalam. 2011. Manajemen Keperawatan: Aplikasi dalam praktek keperawatan professional.Jakarta: Salemba Medika

Nursalam. 2013. Metodologi penelitian ilmu keperawatan. Jakarta: Salemba Medika

Pitman, S. 2011. Handbook for clinical supervisor: nursing post graduate programme.Dublin: Royal Collage of surgeon in Ireland 


\section{LAMPIRAN}

INSTRUMEN PENELITIAN

HASIL PENELITIAN

\section{Usia Kepala Ruang dan Ketua Tim}

Tabel 1. Distribusi Frekuensi Kepala ruang dan Ketua Tim Menurut Usia

\begin{tabular}{|c|c|c|}
\hline Usia & Frekuensi & $\begin{array}{c}\text { Persentas } \\
\mathrm{e}\end{array}$ \\
\hline$\leq 31$ & 2 & 8 \\
$>31$ & 21 & 92 \\
\hline Total & 23 & 100 \\
\hline
\end{tabular}

Distribusi frekuensi tingkat usia kepala ruang dan ketua tim paling banyak terdapat dalam kelompok usia lebih dari atau sama dengan 31 tahun sebesar 92\%. Sedangkan untuk kelompok usia diatas 31 tahun $8 \%$.

\section{Jenis Kelamin Kepala Ruang dan Ketua Tim}

Tabel 2. Distribusi Frekuensi Kepala ruang dan Ketua Tim Menurut Jenis Kelamin

\begin{tabular}{|c|c|c|}
\hline Jenis Kelamin & $\begin{array}{c}\text { Frekuen } \\
\text { si }\end{array}$ & $\begin{array}{c}\text { Persen } \\
\text { tase }\end{array}$ \\
\hline Laki-laki & 3 & 13 \\
Perempuan & 20 & 87 \\
\hline Total & 23 & 100 \\
\hline
\end{tabular}

Distribusi frekuensi jenis kelamin kepala ruang dan ketua tim paling banyak berjenis kelamin perempuan $87 \%$ dan yang laki - laki $13 \%$.

\section{Tingkat Pendidikan Keperawatan Kepala Ruang dan Ketua Tim}

Tabel 3. Distribusi Frekuensi Kepala ruang dan Ketua Tim Menurut Pendidikan Keperawatan

\begin{tabular}{|c|c|c|}
\hline $\begin{array}{c}\text { Pendidikan } \\
\text { Keperawatan }\end{array}$ & Frekuensi & $\begin{array}{c}\text { Persentas } \\
\text { e }\end{array}$ \\
\hline $\begin{array}{c}\text { Diploma III } \\
\text { Keperawatan }\end{array}$ & 21 & 92 \\
Ners & 2 & 8 \\
\hline Total & 23 & 100 \\
\hline
\end{tabular}

Distribusi frekuensi tingkat pendidikan keperawatan kepala ruang dan ketua tim paling banyak terdapat dalam kelompok Diploma III Keperawatan sebesar 92 $\%$. Sedangkan Pendidikan Ners sebesar $8 \%$. 


\section{Lama Kerja Kepala Ruang dan Ketua Tim}

Tabel 4. Distribusi Frekuensi Kepala ruang dan Ketua Tim Menurut Lasa Kerja

\begin{tabular}{|c|c|c|}
\hline Masa Kerja & $\begin{array}{c}\text { Frekuens } \\
\mathrm{i}\end{array}$ & Persentase \\
\hline$<10$ Tahun & 3 & 13 \\
$>10$ Tahun & 20 & 87 \\
\hline Total & 23 & 100 \\
\hline
\end{tabular}

Distribusi frekuensi lasa kerja kepala ruang dan ketua tim paling banyak terdapat dalam kelompok lebih dari 10 tahun sebesar $87 \%$. Sedangkan untuk kelompok kurang dari 10 tahun sebesar $13 \%$.

\section{Status Perkawinan Kepala Ruang dan Ketua Tim}

Tabel 5. Distribusi Frekuensi Kepala ruang dan Ketua Tim Menurut Status Perkawinan

\begin{tabular}{|c|c|c|}
\hline Status perkawinan & Frekuensi & Persentase \\
\hline Menikah & 23 & 100 \\
Belum Menikah & 0 & 0 \\
\hline Total & 23 & 100 \\
\hline
\end{tabular}

Distribusi frekuensi status perkawinan kepala ruang dan ketua tim paling banyak terdapat dalam kelompok menikah sebesar $100 \%$.

6. Tingkat Pengetahuan Kepala Ruang dan Ketua Tim dalam Pelaksanaan Supervisi Model 4S Sebelum diberikan Pendampingan

Tabel 6. Distribusi Frekuensi Tingkat Pengetahuan Supervisi Model 4S Kepala Ruang dan Ketua Tim Sebelum diberikan Sosialisasi Di Ruang rawat Inap Rumah Sakit Muhammadiyah Bandung

\begin{tabular}{|r|l|r|r|}
\hline \multicolumn{1}{|c|}{ No } & Kategori & Frekuensi & \multicolumn{1}{|c|}{ Persentase } \\
\hline 1 & Tinggi & 4 & 17 \\
\hline 2 & Sedang & 9 & 39 \\
\hline 3 & Rendah & 10 & 43 \\
\hline & Jumlah & 23 & 100 \\
\hline
\end{tabular}

Berdasarkan hasil tabel 6.dapat dilihat bahwa tingkat pengetahuan pelaksanaan supervisi klinik keperawatan kepala ruang dan ketua tim model 4S di Ruang Rawat Inap Rumah Sakit Muhammadiyah Bandung sebelum diberikan sosialisasi supervisi didapatkan hasil dalam kategori kurang baik sebesar $43 \%$.

7. Tingkat Pengetahuan Kepala Ruang dan Ketua Tim dalam Pelaksanaan Supervisi Model 4S Setelah diberikan Pendampingan

Tabel 7. Distribusi Frekuensi Tingkat Pengetahuan Supervisi Model 4S Kepala Ruang dan Ketua Tim Model 4S Setelah diberikan Sosialisasi Di Ruang rawat Inap Rumah Sakit Muhammadiyah Bandung

\begin{tabular}{|c|l|r|r|}
\hline No & Kategori & Frekuensi & Persentase \\
\hline 1 & Baik & 23 & 100 \\
\hline
\end{tabular}




\begin{tabular}{|r|l|r|r|}
2 & Cukup & 0 & 0 \\
\hline 3 & Kurang & 0 & 0 \\
\hline & Jumlah & 23 & 100 \\
\hline
\end{tabular}

Berdasarkan hasil tabel 7. dapat dilihat bahwa tingkat pengetahuan supervisi model 4S kepala ruang dan ketua tim model 4S di Ruang Rawat Inap Rumah Sakit Muhammadiyah Bandung setelah diberikan sosialisasi didapatkan hasil kategori baik sebesar $100 \%$.

\section{Sikap Kepala Ruang dan Ketua Tim dalam Pelaksanaan Supervisi Model 4S Sebelum diberikan Pendampingan}

Tabel 8. Distribusi Frekuensi Sikap Pelaksanaan Supervisi Klinik Keperawatan Kepala Ruang dan Ketua Tim Model 4S Sebelum diberikan Pendampingan Di Ruang rawat Inap Rumah Sakit Muhammadiyah Bandung

\begin{tabular}{|r|l|r|r|}
\hline No & Kategori & \multicolumn{1}{|c|}{ Frekuensi } & Persentase \\
\hline 1 & Baik & 4 & 17 \\
\hline 2 & Cukup & 9 & 39 \\
\hline 3 & Kurang & 10 & 43 \\
\hline & Jumlah & 23 & 100 \\
\hline
\end{tabular}

Berdasarkan hasil tabel 8.dapat dilihat bahwa sikap pelaksanaan supervisi klinik keperawatan kepala ruang dan ketua tim model 4S di Ruang Rawat Inap Rumah Sakit Muhammadiyah Bandung sebelum diberikan sosialisasi dan pendampingan teknik supervisi didapatkan hasil dalam kategori kurang baik sebesar $43 \%$.

\section{Sikap Kepala Ruang dan Ketua Tim dalam Pelaksanaan Supervisi Model 4S Setelah diberikan Pendampingan}

Tabel 9. Distribusi Frekuensi Sikap Pelaksanaan Supervisi Klinik Keperawatan Kepala Ruang dan Ketua Tim Model 4S Setelah diberikan Pendampingan Di Ruang rawat Inap Rumah Sakit Muhammadiyah Bandung

\begin{tabular}{|r|l|r|r|}
\hline \multicolumn{1}{|c|}{ No } & Kategori & \multicolumn{1}{|c|}{ Frekuensi } & \multicolumn{2}{c|}{ Persentase } \\
\hline 1 & Baik & 3 & 13 \\
\hline 2 & Cukup & 20 & 87 \\
\hline 3 & Kurang & 0 & 0 \\
\hline & Jumlah & 23 & 100 \\
\hline
\end{tabular}

Berdasarkan hasil tabel 9. dapat dilihat bahwa sikap pelaksanaan supervisi klinik keperawatan kepala ruang dan ketua tim model 4S di Ruang Rawat Inap Rumah Sakit Muhammadiyah Bandung setelah diberikan sosialisasi dan pendampingan teknik supervisi selama 6 hari didapatkan hasil kategori cukup baik sebesar $87 \%$. 


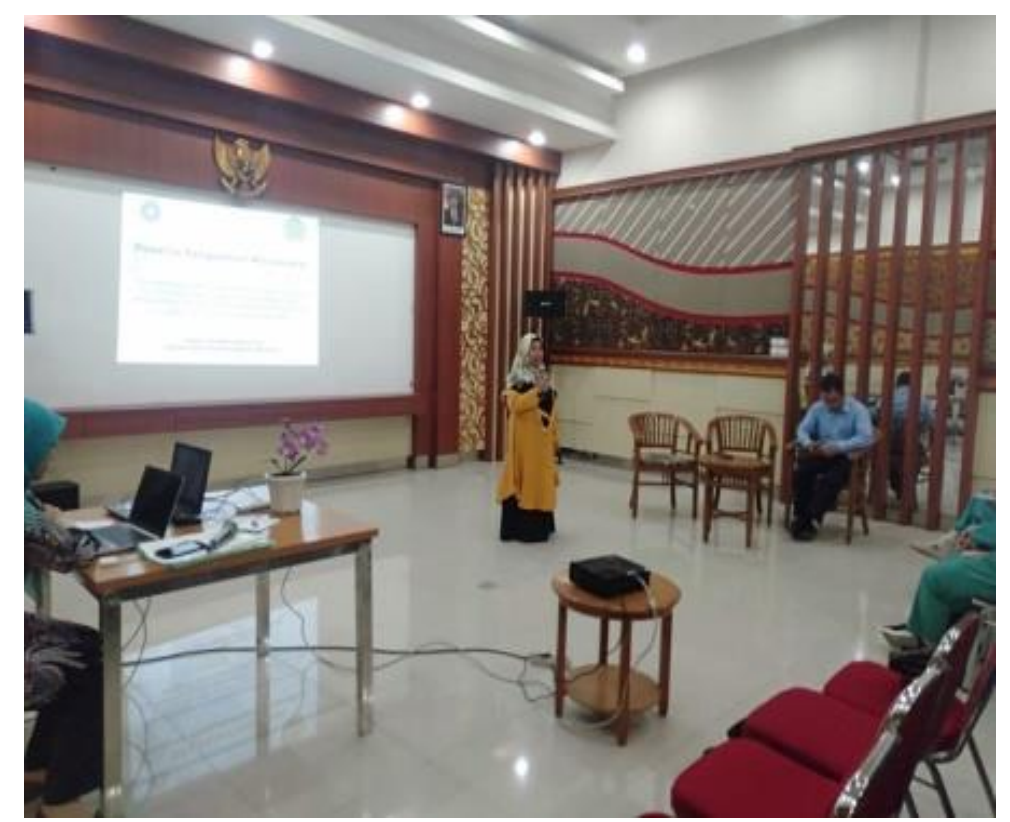

Gambar 1. Pelaksanaan pelatihan peran supervisor model 4S kepada kepala ruang dan ketua tim di Rumah Sakit Muhammadiyah Bandung

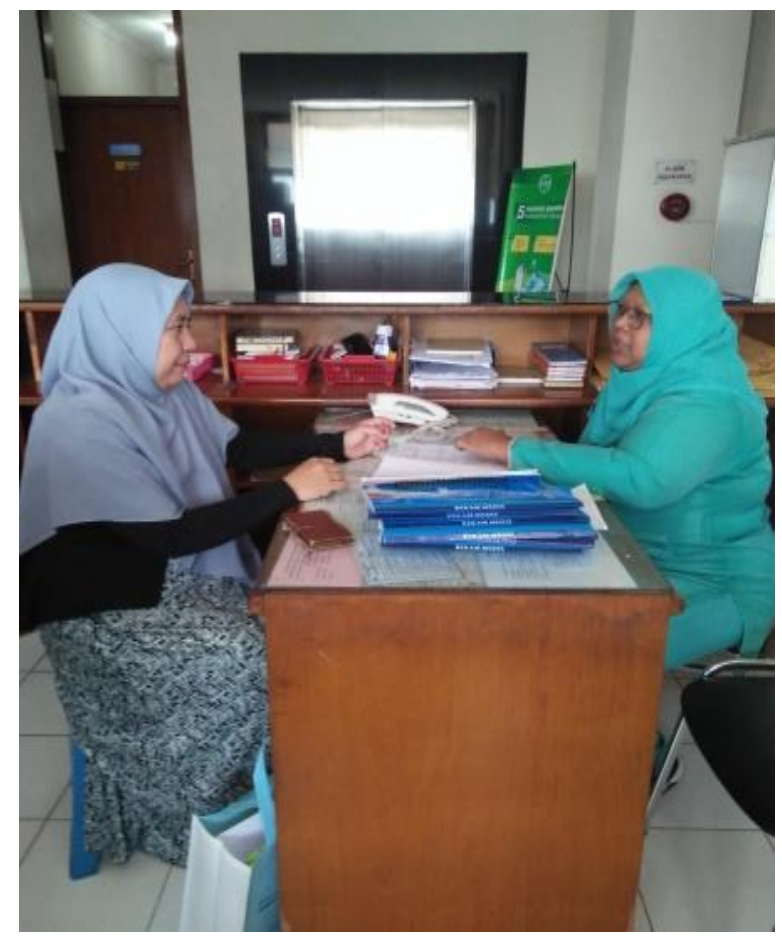

Gambar 2. Pelaksanaan bimbingan pelaksanaan supervisi model 4S kepada kepala ruang dan ketua tim di Rumah Sakit Muhammadiyah Bandung 